\title{
Indium in polymetallic mineralisation at the Gierczyn mine, Karkonosze-Izera Massif, Poland: results of EPMA and LA-ICP-MS investigations
}

\author{
Krzysztof FOLTYN ${ }^{1, *}$, Viktor BERTRANDSSON ERLANDSSON², Gabriela A. KOZUB-BUDZYŃ ${ }^{1}$, \\ Frank MELCHER ${ }^{2}$ and Adam PIESTRZYŃSKI ${ }^{1}$
}

1 AGH University of Science and Technology, al. A. Mickiewicza 30, 30-059 Kraków, Poland

2 Montanuniversität Leoben, Peter-Tunner-Straße 5, 8700 Leoben, Austria

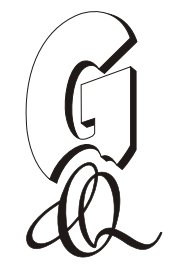

Foltyn, K., Bertrandsson Erlandsson, V., Kozub-Budzyń, G.A., Melcher, F., Piestrzyński, A., 2020. Indium in polymetallic mineralisation at the Gierczyn mine, Karkonosze-Izera Massif, Poland: results of EPMA and LA-ICP-MS investigations. Geological Quarterly, 64 (1): 74-85, doi: 10.7306/gq.1516

Associate Editor: Jacek Szczepański

Cassiterite and base-metal mineralisation from the Gierczyn mine on the Karkonosze-Izera Massif, Poland has been studied using electron microprobe and LA-ICP-MS (Laser Ablation Inductively Coupled Plasma Mass Spectrometry) techniques in order to determine the content of indium in the ore minerals. The main carriers of this element are sphalerite (up to $433 \mathrm{~g} / \mathrm{g}$ of In), chalcopyrite (up to $117 \mathrm{~g} / \mathrm{g}$ of In) and cassiterite (up to $0.02 \mathrm{wt} . \% \mathrm{In}$ ). Trace element contents of sulphides, especially Ga in chalcopyrite intergrown with sphalerite in comparison with chalcopyrite without sphalerite, may indicate metamorphic re-equlibration and suggests that the ore minerals might recrystallized and underwent metamorphism in conditions of greenschist/amphibolite facies. Although the deposits in the Stara Kamienica Schist Belt are not of economic value, they can contribute to better understanding of the relations between trace element partitioning and the formation of ore minerals.

Key words: Gierczyn, indium, trace elements, metamorphism.

\section{INTRODUCTION}

Indium (In) is a crucial commodity for the modern economy due to its application in the form of indium tin oxide (ITO) in almost every flat-panel display screen and in touchscreen devices in computer monitors, TVs, laptops, notebooks and mobile phones. The demand for and price of this element increased rapidly in the first decade of the 21 st century and both are considered to be highly vulnerable for several reasons (Werner et al., 2015). Firstly, the market for this metal is rather small with world refinery production of 750 tonnes in 2018 (Anderson, 2019) and its supply chain is dominated by few countries: China (40\% of world production), South Korea, Japan, Canada, France and Belgium account for $95 \%$ of the world supply (Anderson, 2019). Any new, widespread use could dramatically change the current demand. Additionally, indium is not concentrated enough to constitute a major commodity in ore deposits so it is produced almost solely as a by-product of zinc smelting. As a result, the supply of indium is determined by the supply of zinc, regardless of the market demand for indium. For

\footnotetext{
* Corresponding author, e-mail: kfoltyn@agh.edu.pl

Received: August 9, 2019; accepted: December 12, 2019; first published online: February 27, 2020
}

these reasons indium has been identified as one of the "Critical Raw Materials" by the European Commission in 2011 and in subsequent studies reviewing the list in 2014 and 2017 (EC, 2014; Blengini et al., 2017).

Indium minerals are rare and the most important one, roquesite $\left(\mathrm{CulnS}_{2}\right)$, usually occurs as inclusions in major oreforming minerals such as bornite, chalcopyrite and sphalerite (Schwarz-Schampera and Herzig, 2002). More often, $\operatorname{In}^{3+}$ substitutes for elements with similar ionic radii in base-metal sulphides and relatively high indium concentrations can occur in sphalerite, chalcopyrite, stannite, tin-sulphosalts, tennantite and cassiterite (Schwarz-Schampera, 2013); however, most occurrences of these minerals are subeconomic for indium.

The most important In-bearing deposits are sediment-hosted massive sulphides (SHMS) and volcanogenic massive sulphides (VMS), which account for $>60 \%$ of indium reserves due to the presence of In-enriched sphalerite (Ye et al., 2011; Frenzel et al., 2016; Werner et al., 2017). The concentration of indium in these ores is in the range of 20-200 g/t and typical examples include VMS deposits such as Kidd Creek (Canada), Neves-Corvo (Portugal), Laochang (China), as well as the Bainiuchang and Dabaoshan SEDEX deposits (China) (Ye et al., 2011; Schwarz-Schampera, 2013). The remaining resources reside in skarns, epithermal deposits, polymetallic base-metal vein deposits, granite-related tin-base-metal deposits and Sn-W-Mo porphyry deposits (e.g., Mount Pleasant Canada; Schwarz-Schampera, 2013; Werner et al., 2017). 
Several ore deposits in the Variscan orogenic belt in Europe have been identified to contain significant indium resources (Werner et al., 2017), including VMS deposits in Portugal such as Neves Corvo (In grades varying within the range 20 to 1,100 g/t; Pinto et al., 2014), skarn-type ores in the Pöhla district, Erzgebirge, Germany (Bauer et al., 2019), and polymetallic Sn-base-metal vein- and greisen-type deposits in the Freiberg, Marienberg, Annaberg, and Ehrenfriedersdorf old mining districts, Erzgebirge, Germany (Seifert and Sandmann, 2006; Seifert, 2015). Andersen et al. (2016) investigated indium mineralisation in SW England in detail. They found that Early Permian, granite-related skarn and lode parageneses in this region are enriched in indium, while older sedimentary exhalative and vein parageneses, predating granite emplacement, are largely devoid of it. These authors reported a strong affinity for indium of sulphide-bearing magmatic-hydrothermal assemblages with the highest concentrations found in mineral lodes associated with the Carnmenellis and St Agnes granites. These districts had the highest historical production of tin (with the famous South Crofty Sn-Cu mine) and the indium content locally ex- ceeds 430 g/t. According to Gion et al. (2019), among granites, S- and A-type highly fractionated plutons have the highest probability of being associated with indium-bearing deposits.

According to recent papers, magmatic-hydrothermal mineralisation associated with post-collisional magmatic pulses (especially evolved, peraluminous granites) which have developed skarn, greisen, lode and vein-type mineralisation, represents promising exploration targets for indium (Cook et al., 2011; Pavlova et al., 2015; Seifert, 2015; Andersen et al., 2016; Lerouge et al., 2017). Granites with the highest probability of being associated with indium-rich ores are A- or S-type, highly fractionated intrusions (Gion et al., 2019).

Low-grade tin deposits have been mined for several centuries in the Stara Kamienica Schist Belt (SK) in southwestern Poland, with the last operating mine, "Gierczyn", closed in 1958 (Mochnacka et al., 2015; Fig. 1). Cassiterite mineralisation was accompanied by a polymetallic sulphide/sulphosalt association and additionally, local enrichment in Co minerals resulted in temporary exploitation of cobalt ore nearby Przecznica (Mochnacka et al., 2015). Several investigations (e.g., Piestrzyński

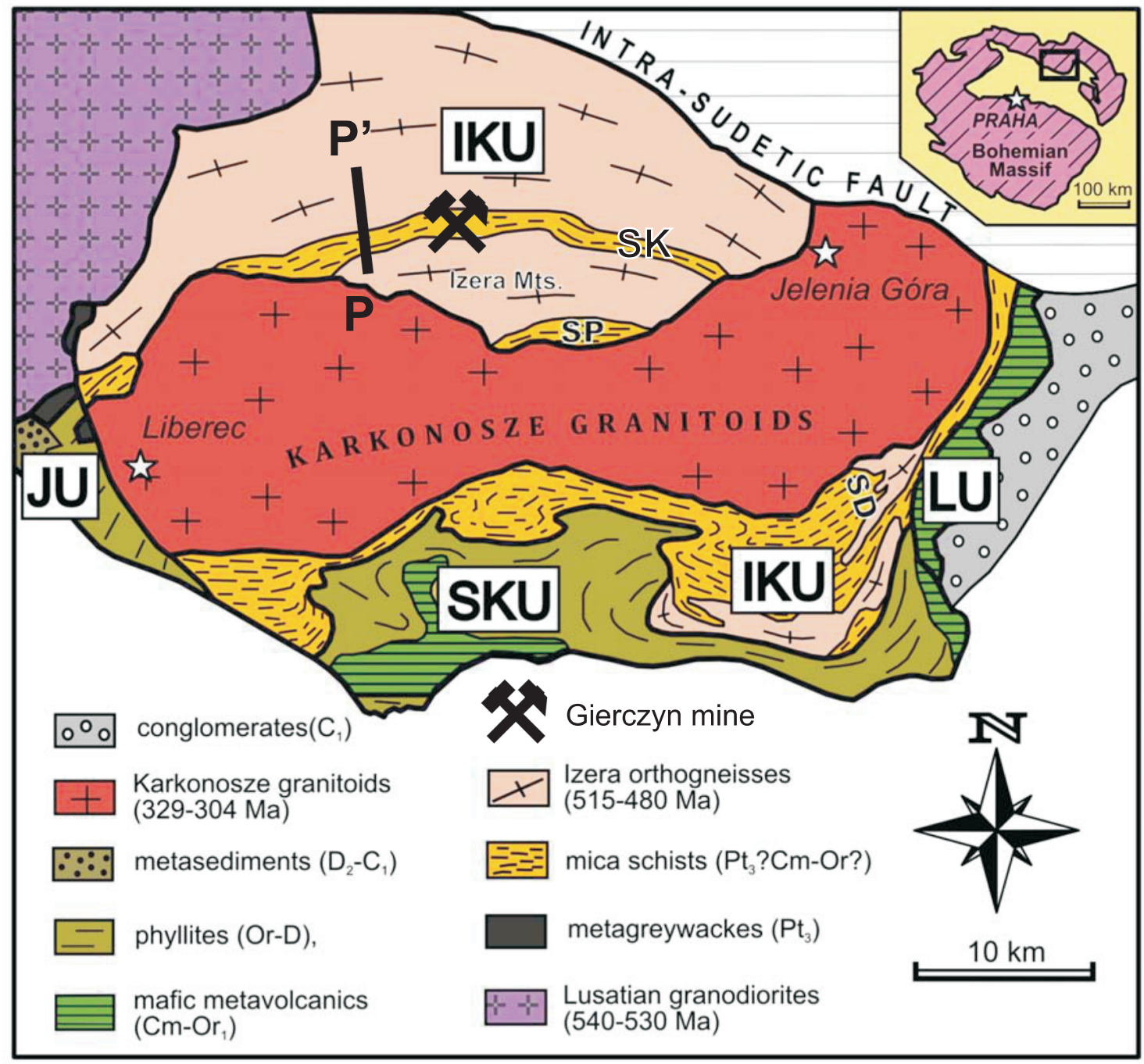

Fig. 1. Geological sketch map of the Karkonosze-Izera Massif

IKU - Izera-Kowary Unit; SKU - South Karkonosze Unit; LU - Leszczyniec Unit; JU - Ješted Unit; SK - Stara Kamienica Belt, SP - Szklarska Poręba Belt (after Kozłowski et al., 2016) 
and Mochnacka, 2003) reported indium in sphalerite and stannite while slight enrichment in this element has also been noted in whole-rock samples (Mikulski et al., 2018; Małek et al., 2019; Mikulski and Małek, 2019). Progress in laser ablation-inductively-coupled mass spectrometry (LA-ICP-MS), provides an opportunity to measure trace elements (including indium) in sulphides at much lower detection limits (e.g., Cook et al., 2009; Ye et al., 2011; George et al., 2016) but so far no LA-ICP-MS data has been published for base-metal mineralisation in the Sudetes Mts. in SW Poland. The aim of this study is to provide new data on minor and trace elements in sulphides from the Gierczyn mine in order to identify the main indium carriers in the deposit.

\section{GEOLOGICAL SETTING}

The Karkonosze-Izera Massif (KIM) is exposed in the west Sudetes on the NE margin of the Bohemian Massif (Fig. 1). It is one of the easternmost exposures of the Variscan crystalline basement in Europe and consists of the Karkonosze Granite and its metamorphic envelope. Granites of the massif crystallized $\sim 312 \mathrm{Ma}$ (Kryza et al., 2014) and are considered to be mostly peraluminous (Słaby and Martin, 2008), transitional between I- and S-type (Słaby and Martin, 2005), while trace elements indicate that the parental magma, enriched in W, Sn, Mo and $\mathrm{Bi}$, was highly-evolved and fractionated (Mikulski, 2007).
These features correspond to granites belonging to the family of Variscan intrusions recognized as a promising exploration target for indium (e.g., Seifert, 2015; Andersen et al., 2016; Lerouge et al., 2017).

The metamorphic envelope of the intrusion includes four different structural units of Neoproterozic-Paleozoic age (Mazur and Aleksandrowski, 2001): the Izera-Kowary Unit (IKU), the Ješted Unit, the Southern Karkonosze Unit and the Leszczyniec Unit (Fig. 1). The Izera-Kowary Unit is divided by the Late Carboniferous Karkonosze pluton into northern and southeastern parts and consists of orthogneisses and mica schists (Figs. 1 and 2). The northern part is referred to in the literature as the Izera Complex built of texturally diverse Izera Gneisses, which enclose lenses of undeformed, coarsely crystalline, porphyritic Izera and Rumburk granites, interpreted as relics of an S-type granitic protolith (Borkowska et al., 1980; Oberc-Dziedzic et al., 2005) and dated at 515-480 Ma (Kröner et al., 2001; Żelaźniewicz et al., 2009). The Izera Complex also contains three schist belts: the northern Złotniki Lubańskie, the central Stara Kamienica and the southern Szklarska Poręba. They are composed of mica schists with minor interbeds of amphibolite, calc-silicate rocks, quartzite and quartz-feldspar schist, and were metamorphosed under conditions of upper greenschist and lower amphibolite facies (Żelaźniewicz et al., 2003).

An extensive review of the ore mineralisation in the KIM was published by Mochnacka et al. (2015). Tin mineralisation had been exploited in the Stara Kamienica Schist Belt since the 16th

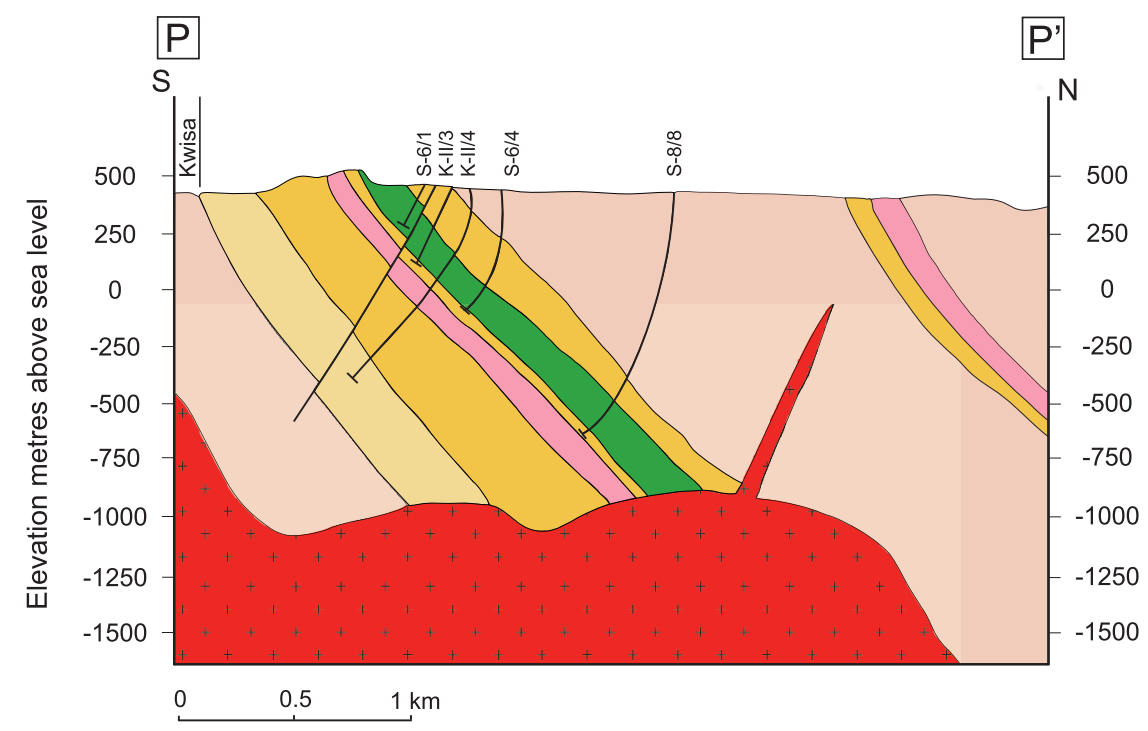

augen gneisses, granito-gneisses, older granites and main member gneisses

thin-banded gneisses, rare intraschist member gneisses

"tin-bearing schists": mica-chlorite-quartz schists with Sn content often $\odot 0.004 \%$

mica schists, mica-quartz schists and mica-chlorite-quartz schists (Sn content $\square 0.004 \%$ )

quartz-feldspar schists

Karkonosze Granite Intrusion

Fig. 2. Schematic cross section of the Stara Kamienica Schist Belt (after Michniewicz et al., 2006, modified) 
century (Madziarz and Sztuk, 2006), but after World War II only exploration works have been conducted. This unit extends from Przecznica in the east, through Gierczyn and Krobica to Czerniawa in the west and further westward, to Nové Město upon Smrek in the Czech Republic. Disseminated in the chlorite-mica-quartz schist rich in almandine garnet, low-grade cassiterite mineralisation forms a stratabound body and is accompanied by a polymetallic sulphide/sulphosalt association (e.g., Jaskólski and Mochnacka, 1959; Speczik and Wiszniewska, 1984; Cook and Dudek, 1994; Mayer et al., 1997; Piestrzyński and Mochnacka, 2003; Michniewicz et al., 2006; Mochnacka et al., 2015 and references therein). Extensive descriptions of ore minerals from this locality have been made e.g. by Speczik and Wiszniewska (1984), Piestrzyński and Mochnacka (2003) and Michniewicz et al. (2006). The ore assemblage in general consists of cassiterite and various sulphides, arsenides and sulphosalts with the most abundant ones being pyrrhotite and chalcopyrite. The mineral succession and different stages of mineralisation have been distinguished in the literature on the basis of calculated temperatures of formation, and an important observation is the presence of two generations of cassiterite (e.g., Mochnacka et al., 1999), considered to be preand post-sulphide. Stannite is present as inclusions in pyrrhotite, sphalerite and chalcopyrite. Mikulski et al. (2018) as well as Mikulski and Małek (2019), reported inclusions ( $10 \mathrm{~m}$ in size) of indium-bearing sakuraiite - $(\mathrm{Cu}, \mathrm{Zn}, \mathrm{Fe})_{3}(\mathrm{In}, \mathrm{Sn}) \mathrm{S}_{4}$, which can contain up to 19 wt.\% of In.

The origin of this tin deposit is still a matter of discussion and several genetic models have been proposed (for detailed reference list see Michniewicz et al., 2006 and Mochnacka et al., 2015), but the most widely accepted ones involve hydrothermal activity. Some authors attributed it to the Ordovician granitic protolith of the Izera Gneisses (e.g., Jaskólski, 1948; Cook and Dudek, 1994; Michniewicz et al., 2006) while others to the Variscan Karkonosze Granite (e.g., Jaskólski and Mochnacka, 1959; Speczik and Wiszniewska, 1984; Mochnacka et al., 2001, 2015). Three schist belts in the IKU are usually considered to be the country rocks for the intrusion of the granitoid protolith of the Izera gneisses ( elaźniewicz et al., 2003) and in this case, pre-Variscan magmatic fluids may be responsible for the tin mineralisation. Michniewicz et al. (2006) concluded their petrographic and structural observations with a statement that the mineralisation is affected by all tectono-metamorphic processes, thus both tin and slightly later sulphides mineralisation seems unlikely to be related to the younger Variscan Karkonosze Granite intrusion. On the other hand, e.g. Speczik and Wiszniewska (1984) argued in favour of the role of hydrothermal fluids associated with intrusion of the Variscan Karkonosze massif in the genesis of ore mineralisation found in the SK. Oberc-Dziedzic et al. (2010), based on zircon dating, proposed that mica schists in the southeastern part of the Izera-Kowary Unit are contemporaneous with the Izera granites and their close proximity is the result of tectonic juxtaposition. Assuming that the Izera Granites are contemporaneous with the mica schist protoliths, the hydrothermal system responsible for the tin accumulation is more likely related to the Variscan Karkonosze Granite (Mochnacka et al., 2015).

\section{SAMPLES AND METHODS}

Five archival samples containing sphalerite and chalcopyrite visible macroscopically, collected by Prof. Ksenia Mochnacka in the now inactive Gierczyn mine, were selected for the study and one-inch polished mounts were prepared from each of them. The suite of samples is limited and was based towards coarse-grained sphalerite and chalcopyrite. Optical light microscopy was used to characterize the ore minerals, paying particular attention to mineral inclusions, zoning, cracks or other textural aspects, all of which may impact trace element distribution. Each sample was also studied by electron microprobe to assess the $\mathrm{Zn}$ and $\mathrm{S}$ contents, which would be used as the internal standards during LA-ICP-MS measurements. Microprobe analyses (EPMA) of chalcopyrite, sphalerite, stannite and cassiterite were carried out using a JEOL JXA-8230 SuperProbe electron microprobe at the Critical Elements Laboratory AGH-KGHM in Kraków. During analyses of the sulphides the electron microprobe was operated in the wavelength-dispersion mode at an accelerating voltage of $20 \mathrm{kV}$ and a probe current of $20 \mathrm{nA}$. Counting times of $20 \mathrm{~s}$ on peak, and of $10 \mathrm{~s}$ on both (-) and (+) backgrounds were used for all elements except $40 \mathrm{~s}$ on peak and $20 \mathrm{~s}$ on background used for In and Sn. For cassiterite, analytical conditions were $15 \mathrm{kV}$ accelerating voltage and $100 \mathrm{nA}$ probe current. Counting times for cassiterite were $20 \mathrm{~s}$ on peak, and $10 \mathrm{~s}$ on both (-) and (+) backgrounds for $\mathrm{Sn}, \mathrm{Ca}, \mathrm{Si}, \mathrm{Fe}, \mathrm{Mn}, 40 \mathrm{~s}$ on peak and $20 \mathrm{~s}$ on background used for $\mathrm{Nb} \mathrm{Ta}, \mathrm{W}$ and $60 \mathrm{~s}$ on peak and $30 \mathrm{~s}$ on background used for In. The following standards and spectral lines were used for sulphides: $\mathrm{FeS}_{2}(\mathrm{FeK} \alpha, \mathrm{SK} \alpha)$, chalcopyrite $(\mathrm{CuK} \alpha)$, ZnS $(\mathrm{ZnK} \alpha), \mathrm{Ag}(\mathrm{AgL} \alpha), \mathrm{In}_{2} \mathrm{Se}_{3}(\mathrm{InL} \alpha), \mathrm{SnS}(\mathrm{SnL} \alpha), \mathrm{Co}(\mathrm{CoK} \alpha)$ and CdS (CdL $\alpha)$, whereas for cassiterite the following were used: cassiterite $(\mathrm{SnL} \alpha)$, albite $(\mathrm{SiK} \alpha)$, rhodonite $(\mathrm{MnK} \alpha)$, scheelite $(\mathrm{WM} \alpha)$, diopside $(\mathrm{CaK} \alpha)$, hematite $(\mathrm{FeK} \alpha)$, manganotantalite $(\mathrm{TaL} \alpha), \operatorname{In}_{2} \mathrm{Se}_{3}(\operatorname{InL} \alpha)$ and $\mathrm{LiNbO}_{3}(\mathrm{NbL} \alpha)$. Detection limits for cassiterite measurements are: $\mathrm{Si}-0.017 \mathrm{wt} \%$, Sn 0.018 wt. \%, $\mathrm{Mn}-0.02$ wt. \%, W - 0.08 wt. \%, $\mathrm{Ca}-0.009$ wt.\%, $\mathrm{Fe}-0.02$ wt.\%, Nb - 0.02 wt.\%, Ta -0.074 wt.\%, In -0.01 wt. $\%, \mathrm{Ti}-0.01$ wt. $\%$. Detection limits for sulphides are: S -0.01 wt.\%, Cu -0.02 wt.\%, Fe - 0.03 wt.\%, Zn - 0.03 wt.\%, In - 0.01 wt.\%, Ag - 0.02 wt.\%, Sn - 0.02 wt.\%, Co - 0.02 wt.\%, Cd 0.02 wt.\%. Data were corrected by the ZAF procedure using $J E O L$ software for electron microprobe.

Electron probe microanalyzer measurement of In content in cassiterite and stannite are complicated by the fact that $\mathrm{Sn}$ X-ray emission lines interfere with those of In (Benzaazoua et al., 2003; Lerouge et al., 2017). In order to eliminate this interference, correction factors were calculated on the basis of EPMA measurements of Sn-bearing standards (cassiterite and SnS) and applied for all EPMA measurement of Sn minerals (they are +0.00091 and +0.00348 for cassiterite and stannite, respectively).

Trace element contents were measured at the Department of Applied Geosciences and Geophysics, Montanuniversität Leoben, Austria, using an ESI NWR213 Nd:YAG laser ablation system coupled to an Agilent $8800 \AA$ triple quadrupole ICP-MS. Helium was used as carrier gas with a flow rate of $0.75 \mathrm{~L} / \mathrm{min}$. Fluency was set between $2-3 \mathrm{~J} / \mathrm{cm}^{2}$. For sphalerite and chalcopyrite analyses, the matrix-matched sintered pressed powder pellet reference material MUL-ZnS 1 (Onuk et al., 2017) was used for quantification of the element content and the USGS powder pressed polysulphide reference material MASS-1 (Wilson et al., 2002) was used for quality control of the analyses. Data reduction was done using the Iolite V3.1 software. The following isotopes were analysed: ${ }^{51} \mathrm{~V},{ }^{52} \mathrm{Cr},{ }^{55} \mathrm{Mn},{ }^{57} \mathrm{Fe},{ }^{59} \mathrm{Co},{ }^{60} \mathrm{Ni}$, ${ }^{63} \mathrm{Cu},{ }^{71} \mathrm{Ga},{ }^{74} \mathrm{Ge},{ }^{75} \mathrm{As},{ }^{82} \mathrm{Se},{ }^{95} \mathrm{Mo},{ }^{107} \mathrm{Ag},{ }^{111} \mathrm{Cd},{ }^{115} \mathrm{In},{ }^{118} \mathrm{Sn}$, ${ }^{121} \mathrm{Sb},{ }^{201} \mathrm{Hg},{ }^{205} \mathrm{TI},{ }^{208} \mathrm{~Pb},{ }^{209} \mathrm{Bi}$. The sphalerite (MUL-ZnS1) and chalcopyrite (MASS-1) reference materials were periodically analysed (every 14 spots) for quality control. Ablation spots were carefully selected in an effort to analyse sphalerite and chalcopyrite free of obvious inclusions or cracks; the samples analysed do nevertheless locally display inhomogeneity on the 
scale of the ablation spot. A consistent $50 \mu \mathrm{m}$ diameter spot size was used for all measurements. The dataset includes 22 spot analyses in massive sphalerite and 24 spot in massive chalcopyrite.

We acknowledge polyatomic interferences that may require corrections to derive precise data using LA-ICP-MS in cases where concentrations of the interfering element are sufficiently high. Taking into account the scope of this paper, mass interference from ${ }^{115} \mathrm{Sn}$ (tin isotope with $0.34 \%$ abundance) needs to be addressed while measuring the content of In (Jenner and O'Neill, 2012). We have not made corrections to the dataset as, although such interferences can impact data quality when the elements concerned are present at wt.\% concentration (e.g., in cassiterite or stannite), we consider them negligible and within instrumental error for the low $\mathrm{g} / \mathrm{g}$ values reported here.

\section{RESULTS}

\section{ORE PETROGRAPHY}

Cassiterite typically occurs as oval grains, usually 50-150 $\mathrm{m}$ in size, but also as multigrain aggregates, found in chlorite and/or mica laminae and concordant with schist foliation (Fig. 3A). In some cases, cassiterite grains seem to be locally pulverized, brecciated and cataclazed during tectonic deformation (Fig. 3B). Zinc and copper mineralisation also occurs as thin veinlets and lenses $(0.5-3 \mathrm{~mm}$ thick), usually parallel with the quartz-chlorite-mica schist foliation (Fig. 3A) but in some cases forming larger massive accumulations up to a few $\mathrm{cm}$ in size. Pyrrhotite, chalcopyrite and sphalerite are the most abundant sulphides (Fig. 3C-E) but traces of galena, cobaltite, native bismuth and bismuthinite have also been found. In some samples pyrrhotite and quartz textures can be described as granoblastic (polygonal and amoeboid) with $\sim 120^{\circ}$ grain boundary contacts (triple junctions; Fig. 3E, F). This texture is often considered as indicative of metamorphism and is formed to minimize grain surface areas and interfacial tension (e.g., Craig and Vaughan, 1994). Stannite is present as small (up to $30 \mathrm{~m}$ ) inclusions in chalcopyrite and pyrrhotite. Sphalerite commonly contains fine chalcopyrite inclusions, so-called "chalcopyrite disease" (Fig. 3D) while small sphalerite inclusions in chalcopyrite and pyrrhotite are rare. The sulphides locally accompany cassiterite (Fig. 3A), but Sn and base-metal mineralisation are commonly spatially separated. SEM-EDS analysis helped to identify numerous small (single to tens of $\mathrm{m}$ in size) grains of native bismuth, bismuthinite $\left(\mathrm{Bi}_{2} \mathrm{~S}_{3}\right)$, laitakarite $\left(\mathrm{Bi}_{4} \mathrm{Se}_{3}\right)$, ullmannite $(\mathrm{NiSbS})$, molybdenite $\left(\mathrm{MoS}_{2}\right)$, a $\mathrm{Ag}_{2}(\mathrm{~S}, \mathrm{Se})$ phase and a $\mathrm{Bi}-\mathrm{Pb}-\mathrm{Ag}-\mathrm{Se}-\mathrm{S}$ sulphosalt similar in composition to wittite or weibullite (Fig. $3 G, H$ ). The main gangue minerals are quartz (usually polygonal; Fig. 3F), idiomorphic almandine garnet (up to several $\mathrm{mm}$ in size), chlorites and micas (muscovite and biotite).

\section{EPMA}

Massive sphalerite from the Gierczyn mine is composed of $58.1 \pm 0.61$ wt. $\% \mathrm{Zn}, 33.76 \pm 0.26$ wt. $\% \mathrm{~S}$ and $8.1 \pm 0.62$ wt. $\% \mathrm{Fe}$ on average (Table 1). Cadmium was consistently detected with mean concentrations of 0.43 wt.\% (Table 1). Cobalt contents up to 0.05 wt. $\%$ (0.03 wt. $\%$ on average) and In concentrations up to 0.06 wt.\% (0.04 wt.\% on average) have been detected (Table 1). By comparison, sphalerite present as minute (tens of $m$ in size) inclusions in sulphides differs slightly from massive sphalerite: it has a lower $\mathrm{Zn}$ content but higher average contents of $\mathrm{Cd}(1.70$ wt.\%) and In (0.1 wt.\%; Table 1).

Chalcopyrite grains, both massive and present as inclusions in sphalerite, have a similar chemical composition and contain $34.00 \pm 0.19$ wt. \% Cu, $29.86 \pm 0.17$ wt.\% Fe and 35.10 \pm 0.18 wt. $\%$ S on average (Table 1). Zinc, Sn and Ag were consistently detected with mean concentrations $\sim 0.09,0.04$ and 0.03 wt.\% respectively, except for small chalcopyrite inclusions in sphalerite where $\mathrm{Zn}$ content reached up to $0.67 \mathrm{wt} . \%$, though these measurements can be affected by surrounding sphalerite (Table 1). Indium content has been measured up to 0.03 wt.\% ( 0.01 wt. \% on average, close to detection limits; Table 1). Most stannites are present as minute inclusions in pyrrhotite and do not carry indium; only those intergrown with a tiny $\mathrm{Pb}-\mathrm{Bi}-\mathrm{Ag}$ Se-S sulphosalt contain detectable amounts of In (up to 0.04 wt.\%, Table 1). Average composition of stannite is $29.86 \pm 0.25$ wt. \% S, $28.49 \pm 0.85$ wt. \% Cu, $26.96 \pm 0.60$ wt.\% Sn and 13.87 \pm 1.18 wt. $\%$ of Fe (Table 1 ).

Cassiterite associated with sulphides contains Fe, Ti, W, In as trace elements but besides Fe, they are usually below or very close to detection limits. Most measuring spots show In below or very close to detection limits of $0.01 \mathrm{wt}$ \% (Table 2). For further investigations on major substitutions of trace elements in cassiterite, crystallochemical formulae were calculated on the basis of six oxygen atoms according to Lerouge et al. (2017). While most of the elements are below or close to detection limits, a strong 1:1 correlation between $\mathrm{Sn}^{4+}$ and $\mathrm{Fe}^{2+}$ is observed $\left(R^{2}=0.99\right)$ and confirms major substitution $\mathrm{Sn}^{4+}-2 \mathrm{Fe}^{2+}$.

\section{$L A-I C P-M S$}

\section{SPHALERITE}

The ablation profiles for some elements (In, Mn, Cd, Fe, Co, $\mathrm{Hg}$ ) are smooth and flat (Fig. 4) indicating homogeneity on the scale of the ablation crater and, implicitly, occurrence of the element in solid solution. Time-resolved depth profiles for $\mathrm{Cu}$ are rarely flat and usually show characteristic spikes (Fig. 4B), interpreted as a result of small chalcopyrite inclusions in the ablated spot. Other elements, notably Sn, Ga, Ag and Se commonly exhibit irregular profiles (Fig. 4), suggesting the presence of micro- or nanoscale inclusions of minerals carrying these elements. Sn and Ag profiles commonly display a slight increase positively correlated with Cu spikes (Fig. 4B) which indicates that "chalcopyrite disease" is enriched in these elements in comparison with the host sphalerite. LA-ICP-MS measurements are summarized in Table 3 and results in general match those determined by EPMA (Table 1). Signifcant Fe and Cd contents (8.53-11.80 wt.\% and 3945-5405 g/g respectively) as well as In enrichment in the range of $347-433 \mathrm{~g} / \mathrm{g}$ have been measured (Table 3 ). Copper exhibits a wide range of concentrations (301-6894 g; Table 3), a result of small chalcopyrite inclusions. Sphalerites also contain notable Co (182-225 g/g; Table 3) which shows strong positive correlation with $\mathrm{Zn}$ and $\mathrm{Cd}\left(\mathrm{R}^{2}=0.67\right.$ and $\mathrm{R}^{2}=0.8$ respectively). Up to $4.6 \mathrm{~g} / \mathrm{g}$ of $\mathrm{Ga}$ has been measured; $\mathrm{Ag}, \mathrm{As}, \mathrm{Pb}, \mathrm{Sn}, \mathrm{Sb}$ and $\mathrm{Bi}$ are typically $<2 \mathrm{~g} / \mathrm{g}$ while $\mathrm{Ge}, \mathrm{Mo}, \mathrm{Ni}, \mathrm{V}$ and $\mathrm{Te}$ do not exceed the background level (Table 3). 

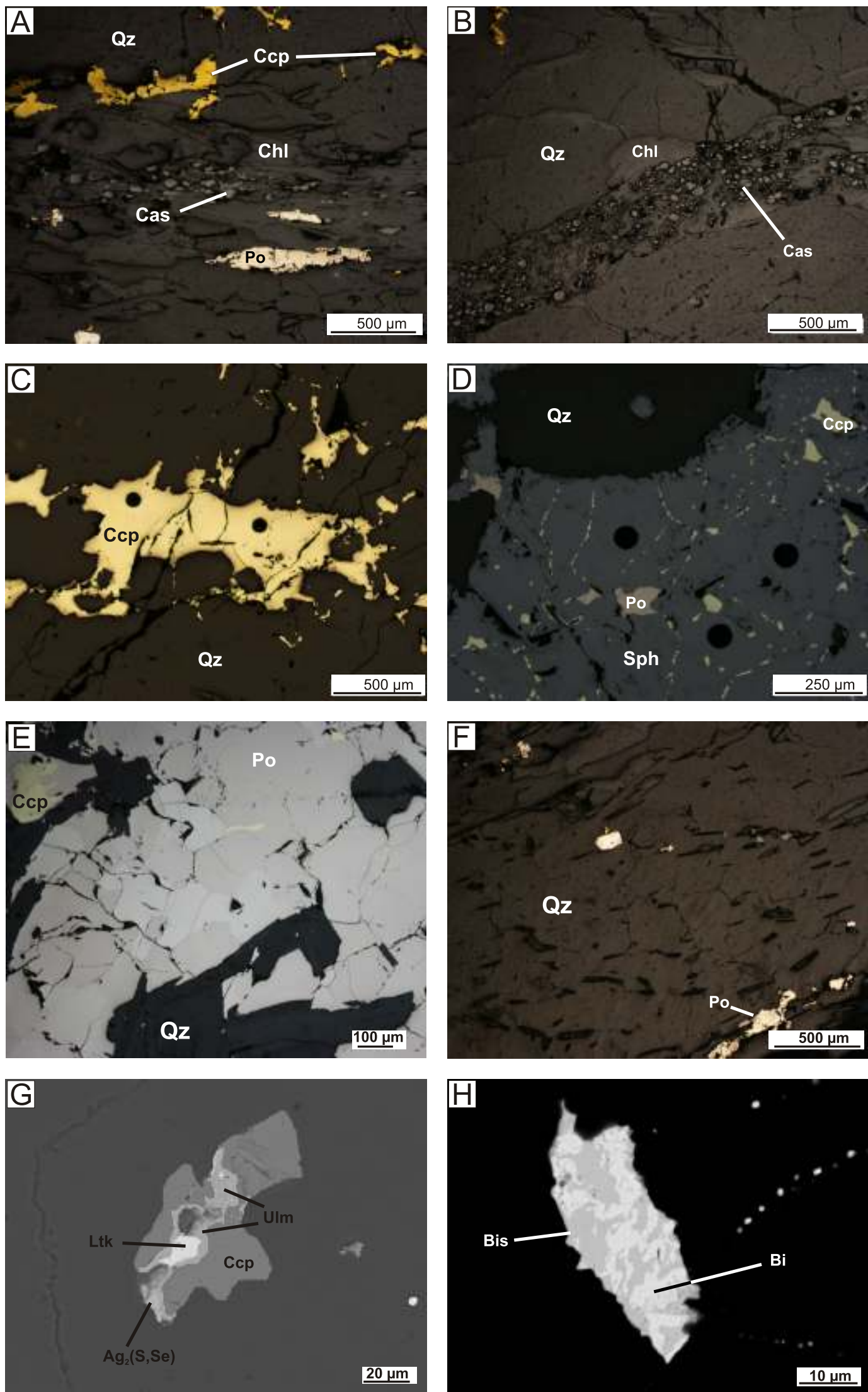

Fig. 3. Ore minerals from the Gierczyn mine, reflected light images

A - oval cassiterite grains in chlorite laminas in quartz accompanied by chalcopyrite and pyrrhotite, $\mathbf{B}$ - cataclastic cassiterite, $\mathbf{C}$ - chalcopyrite with LA-spots in quartz, D - exsolution of chalcopyrite and pyrrhotite in sphalerite with LA-spots, $\mathbf{E}$ - massive pyrrhotite with polygonal morphology, note the $\sim 120^{\circ}$ grain boundary contacts, $\mathbf{F}$ - quartz with polygonal texture; BSE images: $\mathbf{G}$ - intergrowth of laitakarite, ullmannite, chalcopyrite and $\mathrm{Ag}_{2}(\mathrm{~S}, \mathrm{Se})$ phase in quartz; $\mathbf{H}$ - intergrowths of native bismuth and bismuthinite; Cas - cassiterite, Chl - chlorite, Qz - quartz, Ccp chalcopyrite, Po - pyrrhotite, Sph - sphalerite, Ltk - laitakarite, Ulm - ullmannite, Bi - native bismuth, Bis - bismuthinite 
Representative EPMA measurements of sulphides and sulphosalts from the Gierczyn mine (in wt.\%)

\begin{tabular}{|c|c|c|c|c|c|c|c|c|c|c|}
\hline & $S$ & $\mathrm{Fe}$ & $\mathrm{Cu}$ & $\mathrm{Zn}$ & Co & $\mathrm{Cd}$ & $\ln$ & $\mathrm{Ag}$ & Sn & Total \\
\hline \multirow{5}{*}{ Massive sphalerite } & 33.77 & 7.80 & $<0.03$ & 58.27 & 0.04 & 0.39 & 0.04 & n.a. & n.a. & 100.33 \\
\hline & 33.59 & 7.69 & $<0.03$ & 58.24 & 0.04 & 0.45 & 0.03 & n.a. & n.a. & 100.06 \\
\hline & 33.98 & 8.57 & $<0.03$ & 57.68 & 0.03 & 0.43 & 0.04 & n.a. & n.a. & 100.74 \\
\hline & 33.50 & 6.65 & $<0.03$ & 59.25 & $<0.02$ & 0.46 & $<0.01$ & n.a. & n.a. & 99.87 \\
\hline & 33.71 & 8.11 & $<0.03$ & 58.21 & 0.04 & 0.41 & 0.04 & n.a. & n.a. & 100.53 \\
\hline \multirow{2}{*}{$\begin{array}{l}\text { Sphalerite } \\
\text { inclusions }\end{array}$} & 33.15 & 7.45 & $<0.03$ & 57.46 & $<0.02$ & 1.68 & 0.07 & n.a. & n.a. & 99.83 \\
\hline & 33.26 & 6.99 & 0.05 & 57.76 & 0.03 & 1.70 & 0.15 & n.a. & n.a. & 99.95 \\
\hline \multirow{5}{*}{ Massive chalcopyrite } & 35.11 & 29.91 & 34.06 & 0.05 & n.a. & n.a. & $<0.01$ & 0.06 & 0.07 & 99.28 \\
\hline & 35.28 & 29.98 & 34.05 & 0.07 & n.a. & n.a. & $<0.01$ & 0.03 & 0.05 & 99.46 \\
\hline & 35.09 & 29.96 & 34.11 & 0.07 & n.a. & n.a. & $<0.01$ & 0.03 & 0.06 & 99.33 \\
\hline & 34.86 & 29.92 & 34.30 & 0.05 & n.a. & n.a. & $<0.01$ & 0.02 & $<0.02$ & 99.15 \\
\hline & 35.11 & 29.99 & 33.85 & 0.04 & n.a. & n.a. & $<0.01$ & $<0.02$ & 0.04 & 99.05 \\
\hline \multirow{2}{*}{$\begin{array}{l}\text { Chalcopyrite } \\
\text { inclusions }\end{array}$} & 34.91 & 29.68 & 33.79 & 0.42 & n.a. & n.a. & $<0.01$ & 0.02 & 0.04 & 98.88 \\
\hline & 35.14 & 29.93 & 33.52 & 0.67 & n.a. & n.a. & $<0.01$ & 0.02 & $<0.02$ & 99.29 \\
\hline \multirow{3}{*}{ Stannite } & 30.26 & 16.28 & 26.93 & 1.21 & n.a. & n.a. & $<0.01$ & 0.06 & 25.46 & 100.20 \\
\hline & 29.71 & 13.53 & 27.61 & 1.14 & n.a. & n.a. & $<0.01$ & 0.06 & 27.35 & 99.39 \\
\hline & 29.82 & 13.76 & 28.20 & 1.26 & n.a. & n.a. & 0.04 & 0.05 & 27.18 & 100.33 \\
\hline & $S$ & $\mathrm{Fe}$ & $\mathrm{Zn}$ & $\mathrm{Ag}$ & $\mathrm{Bi}$ & $\mathrm{Cu}$ & $\mathrm{Sb}$ & $\mathrm{Pb}$ & $\mathrm{Se}$ & Total \\
\hline Laitakarite & 0.33 & 0.62 & $<0.03$ & 0.02 & 78.25 & 0.97 & 0.07 & 0.05 & 19.30 & 99.61 \\
\hline \multirow{3}{*}{$\begin{array}{l}\text { Bi-Pb-Ag-Se-S } \\
\text { sulphosalt }\end{array}$} & 15.67 & 5.67 & $<0.03$ & 1.82 & 40.59 & 5.53 & 0.23 & 24.93 & 6.53 & 100.97 \\
\hline & 12.86 & 2.36 & $<0.03$ & 5.54 & 44.84 & $<0.03$ & 0.52 & 26.63 & 6.88 & 99.63 \\
\hline & 14.64 & 2.51 & $<0.03$ & 1.82 & 46.23 & 3.15 & 0.07 & 29.50 & 4.45 & 102.37 \\
\hline
\end{tabular}

n.a. - not analysed; detection limits for $\ln -0.01$ wt.\%

Sphalerite incorporates many metals into its structure: $\mathrm{Cu}^{2+}$, $\mathrm{Ni}^{2+}, \mathrm{Co}^{2+}, \mathrm{Fe}^{2+}, \mathrm{Mn}^{2+}$ and $\mathrm{Cd}^{2+}$ which substitute for $\mathrm{Zn}$ via the simple substitution equation $\mathrm{M}^{2+}-\mathrm{Zn}^{2+}$. For elements generally occurring in odd valences such as $\mathrm{Cu}$, In and other trace compounds (e.g., Sb, Ag, Ga, As), multiple coupled substitutions with $\mathrm{Zn}$ are thought to be involved to explain the enrichment of the elements in sphalerite (Johan, 1988; Cook et al., 2012, Belissont et al., 2014). The accepted mechanism of In incorporation into sphalerite is $2 \mathrm{Zn}^{2+}-\mathrm{Cu}^{+}+\mathrm{In}^{3+}$ (Cook et al., 2009, 2012) and given very low concentrations of $\mathrm{Ag}$ in the samples measured, mainly $\mathrm{Cu}$ is involved in the coupled substitution.

\section{CHALCOPYRITE}

Ablation profiles for some elements (In, Mn, Sn, Ag, Co) are smooth and show flat patterns indicating homogeneity on the scale of the ablation crater (Fig. 5) and occurrence of the element in solid solution. Other elements (Cd, Zn, Ga, Se, Sb, Pb, Bi) commonly exhibit less regular profiles, which are likely a combination of lattice-bound element and sub-microscopic inclusions of minerals that contain them (most evident in the case of $\mathrm{Pb}$ and $\mathrm{Bi}$; Fig. 5A).

Measurements confirmed that chalcopyrite from Gierczyn is indeed enriched in In (38-125 g/g; Table 3). It contains typi- cally over $400 \mathrm{~g} / \mathrm{g}$ of $\mathrm{Zn}, 100 \mathrm{~g} / \mathrm{g}$ of $\mathrm{Ag}$ and $225 \mathrm{~g} / \mathrm{g}$ of $\mathrm{Sn}$ (Table 3). Selenium is present at the level of tens of $\mathrm{g} / \mathrm{g}$; Co, $\mathrm{Ga}, \mathrm{Cd}, \mathrm{Sb}, \mathrm{Pb}, \mathrm{Bi}$ are present in almost all analysed spots at the single $\mathrm{g} / \mathrm{g}$ level while $\mathrm{Ge}, \mathrm{As}, \mathrm{Ni}, \mathrm{Mo}, \mathrm{Te}, \mathrm{Hg}$ and $\mathrm{Tl}$ are present at or below detection limits (Table 3).

Chalcopyrite is isostructural with roquesite $\left(\mathrm{CulnS}_{2}\right)$ and as a result, significant concentrations of In can be hosted in chalcopyrite (Wittmann, 1974). Incorporation of trace elements into the chalcopyrite structure is more complex than in the case of sphalerite or galena due to the presence of covalent bonding (see discussion in George et al., 2016, 2018). Coupled substitutions are difficult to verify because $\mathrm{Fe}$ and $\mathrm{Cu}$ is much more concentrated than In and is likely involved in many coupled substitution mechanisms that are impossible to distinguish in simple scatter plots.

\section{DISCUSSION}

Indium content in cassiterite is significantly lower than in samples from Cornwall where average values for different localities are 121-970 $\mathrm{g} / \mathrm{g}$ of $\mathrm{In}$ in cassiterite (Andersen et al., 2016). Indium concentrations in sphalerites and chalcopyrites from Gierczyn are higher than those reported from stratiform 
EPMA measurements of cassiterite from the Gierczyn mine (data in wt.\%)

\begin{tabular}{|c|c|c|c|c|c|c|c|c|c|c|c|c|}
\hline $\mathrm{WO}_{3}$ & 0.33 & bdl & bdl & bdl & 0.09 & bdl & 0.13 & 0.15 & 0.08 & 0.08 & 0.12 & 0.08 \\
\hline $\mathrm{Nb}_{2} \mathrm{O}_{5}$ & bdl & bdl & bdl & bdl & bdl & bdl & bdl & bdl & bdl & bdl & bdl & bdl \\
\hline $\mathrm{Ta}_{2} \mathrm{O}_{5}$ & bdl & bdl & bdl & bdl & bdl & bdl & bdl & bdl & bdl & bdl & bdl & bdl \\
\hline $\mathrm{SnO}_{2}$ & 99.67 & 98.46 & 98.59 & 98.87 & 99.84 & 100.10 & 99.28 & 99.37 & 100.39 & 100.03 & 100.19 & 99.86 \\
\hline $\mathrm{SiO}_{2}$ & bdl & bdl & bdl & bdl & bdl & bdl & bdl & bdl & bdl & bdl & bdl & bdl \\
\hline MnO & bdl & bdl & bdl & bdl & bdl & bdl & bdl & bdl & bdl & bdl & bdl & 0.02 \\
\hline $\mathrm{FeO}$ & 0.32 & 0.38 & 0.62 & 0.67 & 0.86 & 0.46 & 0.32 & 1.49 & 0.50 & 0.27 & 0.34 & 0.51 \\
\hline $\mathrm{CaO}$ & bdl & bdl & bdl & bdl & 0.02 & 0.01 & 0.03 & 0.01 & 0.02 & 0.02 & 0.02 & bdl \\
\hline $\ln _{2} \mathrm{O}_{3}$ & bdl & 0.01 & 0.02 & bdl & 0.01 & bdl & 0.01 & 0.01 & 0.01 & 0.01 & 0.01 & 0.02 \\
\hline $\mathrm{TiO}_{2}$ & bdl & bdl & bdl & 0.03 & bdl & bdl & bdl & bdl & bdl & bdl & bdl & bdl \\
\hline Total & 100.32 & 98.86 & 99.24 & 99.64 & 100.84 & 100.62 & 99.78 & 101.03 & 101.00 & 100.46 & 100.70 & 100.51 \\
\hline \multicolumn{13}{|c|}{ Apfu on the basis of $3 \mathrm{Sn}$} \\
\hline $\mathrm{WO}_{3}$ & 0.006 & 0.000 & 0.000 & 0.000 & 0.002 & 0.000 & 0.002 & 0.003 & 0.002 & 0.001 & 0.002 & 0.002 \\
\hline $\mathrm{Nb}_{2} \mathrm{O}_{5}$ & 0.000 & 0.000 & 0.000 & 0.000 & 0.000 & 0.000 & 0.000 & 0.000 & 0.000 & 0.000 & 0.000 & 0.000 \\
\hline $\mathrm{Ta}_{2} \mathrm{O}_{5}$ & 0.000 & 0.000 & 0.000 & 0.000 & 0.000 & 0.000 & 0.000 & 0.000 & 0.000 & 0.001 & 0.000 & 0.000 \\
\hline $\mathrm{SnO}_{2}$ & 2.974 & 2.975 & 2.960 & 2.956 & 2.943 & 2.970 & 2.976 & 2.904 & 2.967 & 2.979 & 2.976 & 2.965 \\
\hline $\mathrm{SiO}_{2}$ & 0.000 & 0.000 & 0.000 & 0.000 & 0.000 & 0.000 & 0.000 & 0.000 & 0.000 & 0.000 & 0.000 & 0.000 \\
\hline MnO & 0.000 & 0.000 & 0.000 & 0.000 & 0.000 & 0.000 & 0.000 & 0.000 & 0.000 & 0.000 & 0.000 & 0.001 \\
\hline $\mathrm{FeO}$ & 0.020 & 0.024 & 0.039 & 0.042 & 0.054 & 0.028 & 0.021 & 0.092 & 0.031 & 0.018 & 0.021 & 0.031 \\
\hline $\operatorname{In}_{2} \mathrm{O}_{3}$ & 0.000 & 0.000 & 0.001 & 0.000 & 0.000 & 0.000 & 0.000 & 0.000 & 0.000 & 0.000 & 0.000 & 0.001 \\
\hline $\mathrm{TiO}_{2}$ & 0.000 & 0.000 & 0.000 & 0.002 & 0.000 & 0.000 & 0.000 & 0.000 & 0.000 & 0.000 & 0.000 & 0.000 \\
\hline Total & 3.000 & 3.000 & 3.000 & 3.000 & 3.000 & 3.000 & 3.000 & 3.000 & 3.000 & 3.000 & 3.000 & 3.000 \\
\hline
\end{tabular}

bdl - below detection limit; structural formulae were calculated on the basis of six oxygen atoms (as in Lerouge et al., 2017)

pre-granite sulphides from Cornwall (mostly below the lower limit of detection, outliers up to $242 \mathrm{~g} / \mathrm{g}$ of $\mathrm{In}$ in sphalerite and $42 \mathrm{~g} / \mathrm{g} \mathrm{In}$ in chalcopyrite), but not as high as those from granite-related skarns from that locality (e.g., sphalerite from the Haytor Vale Mine contains up to 1300 and $540 \mathrm{~g} / \mathrm{g}$ In on average; Andersen et al., 2016). Indium contents up to $250 \mathrm{~g} / \mathrm{g}$ in chalcopyrite (80 $\mathrm{g} / \mathrm{g}$ on average) are significantly lower than data reported from thirteen $\mathrm{S} n \pm \mathrm{W}$ granite-related ore deposits in the western Variscan Belt (Massif Central and Armorican Massif, France; Galicia, Spain; and SW England) by Lerouge et al. (2017) where contents reach $2870 \mathrm{~g} / \mathrm{g}$. Sphalerite from the Freiberg district also contains much higher In concentrations, between 0.03 and 0.38 wt. $\%$ In (mean value 0.16 wt.\%; Seifert and Sandmann, 2006). Considering available LA-ICP-MS data for trace elements in chalcopyrite for different ore deposit types, the values show similarities to proximal orepipe samples from the Baita Bihor Cu-Au-Pb-Zn-Mo skarn deposit in Romania (George et al., 2016, 2018) with In concentrations around 100 $\mathrm{g} / \mathrm{g}$, Sn and Co concentrations at tens and hundreds of $\mathrm{g} / \mathrm{g}$ and very low contents of As. The Baita Bihor skarn is a result of contact metamorphism (Ciobanu et al., 2002), contains Cu-Zn$\mathrm{Pb}-\mathrm{W}-\mathrm{Bi}$ ores, and the estimated temperature of formation for proximal zone pipes is $500^{\circ} \mathrm{C}$ (George et al., 2018). Sphalerite with low concentrations of As and $\mathrm{Ge}$, together with enrichment in Co, as in the case of the Gierczyn samples, are often reported in skarn deposits (e.g., Cook et al., 2009; Frenzel et al., 2016; George et al., 2016) and usually indicate a higher temperature of formation.

The formation of In-rich sulphides may be facilitated by high-temperature precipitation from the hydrothermal fluid or recrystallization processes e.g. due to metamorphic overprinting (Schwarz-Schampera and Herzig, 2002). Co-precipitation of In with $\mathrm{Cu}, \mathrm{Zn}$ and $\mathrm{Fe}$ accounts for the elevated concentrations in chalcopyrite ores and is characterized by formation temperatures in the range of $\sim 290-380^{\circ} \mathrm{C}$ with a general rise in In concentrations in ore minerals with depth and increasing formation temperatures (Schwarz-Schampera and Herzig, 2002). Cook and Dudek (1994) used sphalerite from the Stara Kamienica Schist Belt as a geothermometer and their data suggest temperatures $500-550^{\circ} \mathrm{C}$ and pressure $6-7.5 \mathrm{kbars}$. Frenzel et al. (2016) in their meta-analyses of trace elements in sphalerite showed statistically significant differences in the mean concentrations of $\mathrm{Fe}, \mathrm{Ga}, \mathrm{Ge}$, In and $\mathrm{Mn}$ in sphalerite between different deposit types. Statistical calculation allowed them to demonstrate that concentration of these elements strongly correlates with the homogenisation temperature of 

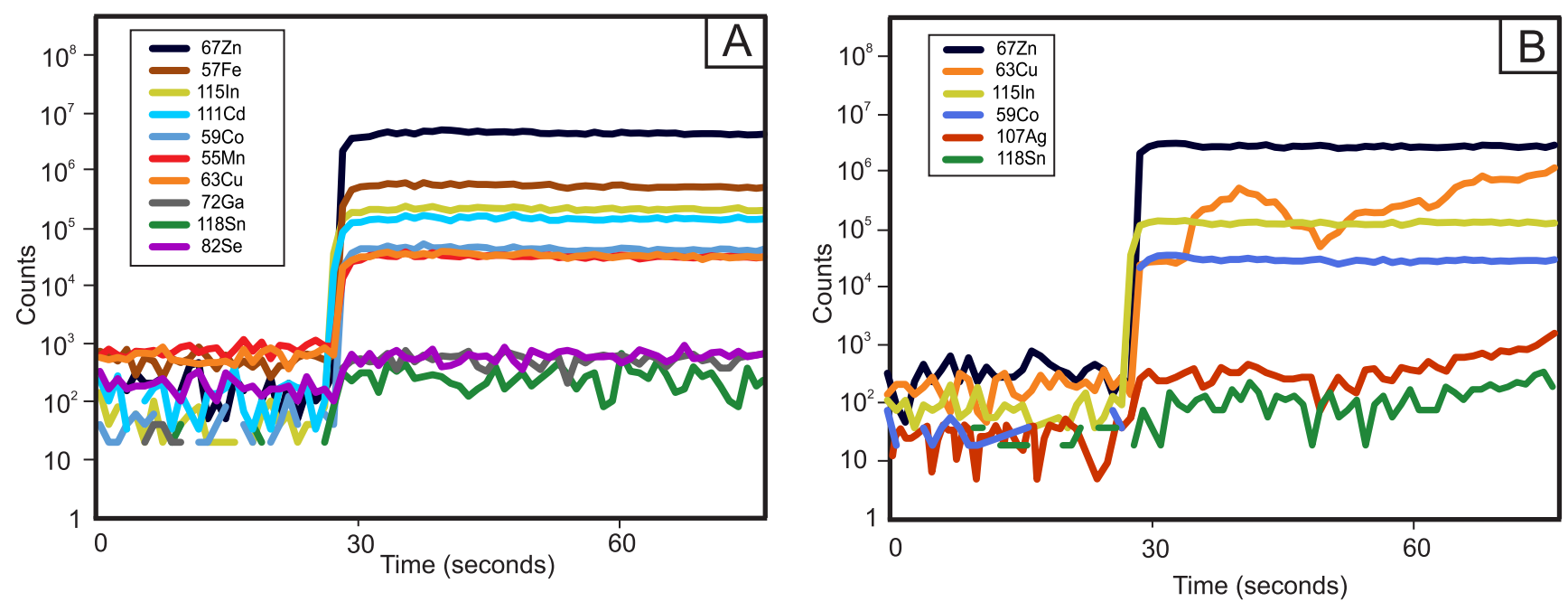

Fig. 4. Representative single-spot LA-ICP-MS spectra for selected elements in sphalerite

A - free of chalcopyrite inclusions, B - with "chalcopyrite disease"

Table 3

The results of LA-ICP-MS measurements in $\mu \mathrm{g} / \mathrm{g}$ for selected elements

\begin{tabular}{|c|c|c|c|c|c|c|c|c|c|c|c|c|c|c|c|c|c|}
\hline & $\mathrm{Mn}$ & $\mathrm{Fe}$ & Co & $\mathrm{Ni}$ & $\mathrm{Cu}$ & $\mathrm{Zn}$ & $\mathrm{Ga}$ & $\mathrm{Ge}$ & As & $\mathrm{Se}$ & $\mathrm{Ag}$ & $\mathrm{Cd}$ & In & Sn & $\mathrm{Sb}$ & $\mathrm{Pb}$ & $\mathrm{Bi}$ \\
\hline \multicolumn{18}{|c|}{ Sphalerite } \\
\hline MEDIAN (22) & 87 & 101098 & 195 & 0.2 & 677 & IS & 3.8 & 0.3 & 0.6 & 65 & 1.7 & 4168 & 359 & 1.6 & 0.3 & 0.6 & 0.5 \\
\hline MEAN (22) & 93 & 100985 & 199 & 0.4 & 1517 & IS & 3.9 & 0.3 & 0.5 & 65 & 2.4 & 4467 & 374 & 2.5 & 2.8 & 3.7 & 0.9 \\
\hline MIN & 70 & 85302 & 182 & $<0.1$ & 301 & IS & 2.9 & 0.1 & $<0.1$ & 45.5 & 0.7 & 3945 & 347 & 0.4 & $<0.1$ & $<0.1$ & $<0.1$ \\
\hline MAX & 139 & 118023 & 225 & 4.4 & 6894 & IS & 4.6 & 0.5 & 1.2 & 77 & 7.6 & 5405 & 433 & 11.7 & 47.4 & 59 & 7.9 \\
\hline \multicolumn{18}{|c|}{ Chalcopyrite } \\
\hline MEDIAN (24) & 13.1 & IS & 9.4 & 6.7 & IS & 624 & 1.5 & 0.5 & 0.2 & 86 & 181 & 12.1 & 97 & 623 & 0.7 & 2.1 & 2.1 \\
\hline MEAN (24) & 12.6 & IS & 8.6 & 35 & IS & 663 & 1.6 & 0.5 & 0.2 & 100 & 188 & 23 & 85 & 679 & 1.3 & 2.9 & 2.6 \\
\hline MIN & 10 & IS & 3.3 & 1.5 & IS & 438 & 0.1 & 0.1 & - & 40 & 127 & 3.5 & 38 & 223 & 0.1 & 0.4 & 0.2 \\
\hline MAX & 15.8 & IS & 15.6 & 483 & IS & 1477 & 3.3 & 1.1 & 0.4 & 159 & 293 & 70 & 125 & 1288 & 5 & 15.7 & 8.6 \\
\hline
\end{tabular}

IS - internal standard

fluid inclusions and was the basis for the empirical formula of a new geothermometer GGIMFis („Ga, Ge, In, Mn and Fe in sphalerite”; Frenzel et al., 2016). Application of the GGIMFis geothermometer to our results gave temperatures in the range $331-349^{\circ} \mathrm{C}$. Frenzel et al. (2016) also discussed thoroughly the impact of metamorphism on trace element contents in sphalerite. A plot of GGIMFis temperature against peak metamorphic temperature for the deposits first increase in the ratio $1: 1$ up to $\sim 310^{\circ} \mathrm{C}$ but then remains constant while peak temperature further increases (Frenzel et al., 2016). They interpret this result as reflecting closure of the sphalerite system at $\sim 310^{\circ} \mathrm{C}$ during retrograde metamorphism and conclude that the geothermometer is reset for deposits affected by greenschist or higher grade metamorphism. This means that the results for the Gierczyn samples $\left(331-349^{\circ} \mathrm{C}\right)$ can be interpreted as reflecting the temperature of sphalerite deposition (Variscan, post-metamorphic mineralisation), but they can as well-represent sphalerite metamorphosed in conditions of greenschist/amphibolite facies (thus pre-metamorphic mineralisation).

Metamorphism is basically the re-equilibration of existing mineral assemblages under different temperature and pressure conditions and according to Frenzel et al. (2016) the most important effect of metamorphism on sphalerite in terms of trace elements will be a diminishing of $\mathrm{Ga}$ and $\mathrm{Ge}$ concentrations relative to the concentrations of $\mathrm{Fe}, \mathrm{Mn}$ and, to a lesser degree, In. They point out that this does not necessarily mean that $\mathrm{Ga}$ and Ge will be expelled from the deposit; instead, these elements might partition into other minerals, e.g. the Cu-Fe-sulphides (e.g., Reiser et al., 2011). In recent papers George et al. (2016, 2018) investigated hydrothermal chalcopyrite and the partitioning of elements between co-crystallizing phases using LA-ICP-MS. Their data show that hydrothermal chalcopyrite crystallizing alone is likely to host greater concentrations of Co, Zn, Se, $\mathrm{Ag}, \mathrm{In}, \mathrm{Sn}$ and $\mathrm{Bi}$ than chalcopyrite co-crystallizing with sphalerite (being a preferential host, sphalerite will reduce the 

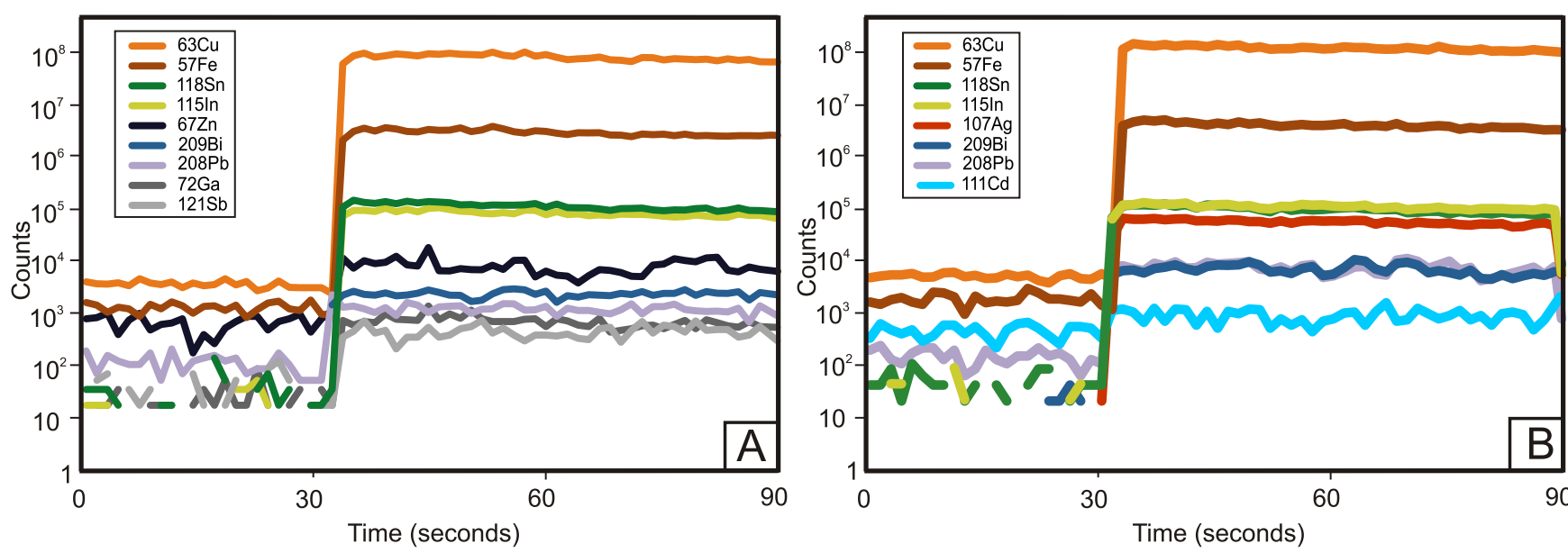

Fig. 5. Representative single-spot LA-ICP-MS spectra for selected elements in chalcopyrite

A - good correlation between $\mathrm{Pb}$ and $\mathrm{Bi}$ could indicate microinclusions of $\mathrm{Pb}$-Bi minerals; B - flat profiles for major elements: $\mathrm{Cu}, \mathrm{Fe}, \mathrm{Sn}, \mathrm{In}, \mathrm{Ag}$

amounts of trace elements available for chalcopyrite). On the other hand, they observed that in the deposits where sulphides recrystallized under metamorphic conditions the opposite is true for $\mathrm{Ga}$ and $\mathrm{Sn}$, which are significantly higher in chalcopyrite co-crystallizing with sphalerite by comparison with chalcopyrite crystallizing alone (George et al., 2018). They proposed that during recrystallization, $\mathrm{Ga}$ and $\mathrm{Sn}$ in pre-existing sphalerite (a preferential host at lower temperatures) have been remobilized and partitioned into co-existing chalcopyrite.

We observe a similar pattern for $\mathrm{Ga}$ in the sulphides investigated from the Gierczyn mine but not for Sn (Table 4); however, in this case the presence or absence of cassiterite and stannite (absent in the deposit investigated by George et al., 2018) is expected to be the main factor influencing the content of Sn in the sulphides. Additionally, we observe that chalcopyrite which occurs together with massive sphalerite has significantly lower Se, Ag, Cd and slightly higher In than chalcopyrite without sphalerite (Table 4).

Two leading hypothesis regarding origin of the tin-sulphide mineralisation in the Stara Kamienica Schist Belt can be summarized as "pre-metamorphic" and "post-metamorphic" respectively, but both invoke intrusion of a granite as a main source of the mineralising fluids i.e. the pre-Variscan granitic protolith of the Izera Gneisses or the Variscan Karkonosze Granite, respectively, which likely could be a source of In (Mochnacka et al., 2015; Gion et al., 2019).
Although the sample set is limited, textural observation of pyrrhotite and quartz with granoblastic polygonal textures (Fig. $3 \mathrm{E}, \mathrm{F})$, as well as partitioning of trace elements between sulphides, are more consistent with the idea that at least part of the tin and base-metal mineralisation underwent metamorphism. This could have been during regional metamorphism directly preceding emplacement of the Karkonosze Granite Intrusion or during earlier metamorphic events. Further investigation providing absolute ages of metamorphism and mineralisation as well as comparison with sulphide occurrences related to the Karkonosze Granite Intrusion are needed to verify this interpretation.

\section{CONCLUSIONS}

With development in analytical techniques, trace elements in sulphides are becoming increasingly useful in deciphering geological processes related to mineral deposits. The low grade tin-sulphide mineralisation in the Stara Kamienica Schist Belt is enriched in indium, with sphalerite (up to $433 \mathrm{~g} / \mathrm{g}$ of $\mathrm{In}$ ), chalcopyrite (up to $117 \mathrm{~g} / \mathrm{g}$ of In) and cassiterite (up to $0.02 \mathrm{wt} \% \mathrm{In}$ ) as the main hosts of this element. Indium, tin and especially gallium present in pre-existing sphalerite may have been remobilized and partitioned into chalcopyrite during metamorphism, thus increasing the concentration of these elements in the lat-

Median of trace elements concentration in chalcopyrite grains which occur together with massive sphalerite ( $n=22$ ablation spots) in comparison with chalcopyrite alone ( $n=13$ ablation spots)

\begin{tabular}{|c|c|c|c|c|c|c|}
\hline & $\mathrm{Ge}$ & Sn & Se & $\mathrm{Ag}$ & $\mathrm{Cd}$ & In \\
\hline & \multicolumn{6}{|c|}{$[\mathrm{g} / \mathrm{g}]$} \\
\hline Chalcopyrite occur with sphalerite & $\begin{aligned} & 2.6 \\
&(\max 3.3 \mathrm{~g} / \mathrm{g}) \\
&\end{aligned}$ & $\begin{array}{r}400 \\
(\max 658 \mathrm{~g} / \mathrm{g}) \\
\end{array}$ & 66 & 143 & 4.5 & 98 \\
\hline Chalcopyrite without sphalerite & $\begin{array}{c}1 \\
(\max 1.8 \mathrm{~g} / \mathrm{g})\end{array}$ & $\begin{array}{cc}817 & \\
(\max 1288 & \mathrm{g} / \mathrm{g})\end{array}$ & 134 & 221 & 43 & 74 \\
\hline
\end{tabular}


ter. Chalcopyrite from Gierczyn occurring together with sphalerite has a higher $\mathrm{Ga}$ content than chalcopyrite occurring without sphalerite, a feature consistent with metamorphic recrystallization of the ore assemblage. Further research on trace elements in sulphides can help answer the question whether they recrystallized in conditions of greenschist/amphibolite facies. Investigation of sulphides from the Karkonosze-Izera Massif as a whole can give interesting insights into trace element partitioning between sulphides affected by contact and/or regional metamorphism.
Acknowledgement. We would like to thank prof. K. Mochnacka for providing samples for measurements. We are also grateful to Dr P. Onuk for his support during LA-ICP-MS analyses and data reduction and to the reviewers, Prof. A. Pieczka and $\mathrm{C}$. Lerouge, whose comments helped us to improve this manuscript. This work was supported by the research subsidy nr. 16.16.140.315 at the Faculty of Geology, Geophysics and Environmental Protection of the AGH University of Science and Technology in Kraków.

\section{REFERENCES}

Andersen, J.C., Stickland, R.J., Rollinson, G.K., Shail, R.K., 2016. Indium mineralisation in SW England: host parageneses and mineralogical relations. Ore Geology Reviews, 78 213-238.

Anderson, C.S., 2019. Indium. In: Mineral Commodity Summaries 2019: 78-79. United States Geological Survey.

Bauer, M.E., Seifert, T., Burisch, M., Krause, J., Richter, N., Gutzmer, J., 2019. Indium-bearing sulfides from the Hämmerlein skarn deposit, Erzgebirge, Germany: evidence for late-stage diffusion of indium into sphalerite. Mineralium Deposita, 54: 175-192.

Belissont, R., Boiron, M.C., Luais, B., Cathelineau, M., 2014. LA-ICP-MS analyses of minor and trace elements and bulk $\mathrm{Ge}$ isotopes in zoned Ge-rich sphalerites from the Noailhac-SaintSalvy deposit (France): insights into incorporation mechanisms and ore deposition processes. Geochimica et Cosmochimica Acta, 126: 518-540.

Benzaazoua, M., Marion, P., Pinto, A., Migeon, H., Wagner, F. E., 2003. Tin and indium mineralogy within selected samples from the Neves Corvo ore deposit (Portugal): a multidisciplinary study. Minerals Engineering, 16: 1291-1302.

Blengini, G., Nuss, P., Dewulf, J., Nita, V., Peirò, L.T., VidalLegaz, B., Latunussa, C., Mancini, L., Blagoeva, D., Pennington, D., Pellegrini, M., Van Maercke, A., Solar, S., Grohol, M., Ciupagea, C., 2017. EU methodology for critical raw materials assessment: policy needs and proposed solutions for incremental improvements. Resources Policy, 53: 12-19.

Borkowska, M., Hameurt, J., Vidal, P., 1980. Origin and age of Izera gneisses and Rumburk granites in the Western Sudetes. Acta Geologica Polonica, 30: 121-146.

Ciobanu, C.L., Cook, N.J., Stein, H., 2002. Regional setting and geochronology of the Late Cretaceous Banatitic magmatic and metallogenetic belt. Mineralium Deposita, 37: 541-567.

Cook, N.J., Ciobanu, C.L., Pring, A., Skinner, W., Shimizu, M., Danyushevsky, L., Saini-Eidukat, B., Melcher, F., 2009. Trace and minor elements in sphalerite: a LA-ICPMS study. Geochimica et Cosmochimica Acta, 73: 4761-4791.

Cook, N.J., Sundblad, K., Valkama, M., Nygård, R., Ciobanu, C.L., Danyushevsky, L., 2011. Indium mineralisation in A-type granites in southeastern Finland: insights into mineralogy and partitioning between coexisting minerals. Chemical Geology, 284: 62-73.

Cook, N.J., Ciobanu, C.L., Brugger, J., Etschmann, B., Howard, D.L., de Jonge, M.D., Ryan, C., Paterson, D., 2012. Determination of the oxidation state of $\mathrm{Cu}$ in substituted $\mathrm{Cu}-\mathrm{In}$-Fe-bearing sphalerite via $\mu$-XANES spectroscopy. American Mineralogist, 97: 476-479.

Cook, N., Dudek, K., 1994. Mineral chemistry and metamorphism of garnet-chlorite mica schists associated with cassiterite-sulfide mineralization from the Kamienica Range, Izera Mountains, SW Poland. Chemie der Erde, 54: 1-32.

Craig, J.R., Vaughan, D.J., 1994. Ore Microscopy and Ore Petrography. 2nd Edition, John Wiley and Sons Inc., Hoboken.
EC-European Commission, 2014. Report on critical raw materials for the EU - report of the Ad hoc Working Group on defining critical raw materials. European Commission. Brussels, 2014.

Frenzel, M., Hirsch, T., Gutzmer, J., 2016. Gallium, germanium, indium, and other trace and minor elements in sphalerite as a function of deposit type - a meta-analysis. Ore Geology Reviews, 76: 52-78.

George, L.L., Cook, N.J., Ciobanu, C.L., 2016. Partitioning of trace elements in co-crystallized sphalerite-galena-chalcopyrite hydrothermal ores. Ore Geology Reviews, 77: 97-116.

George, L.L., Cook, N.J., Crowe, B.B., Ciobanu, C.L., 2018. Trace elements in hydrothermal chalcopyrite. Mineralogical Magazine, 82: $59-88$

Gion, A.M., Piccoli, P.M., Candela, P.A., 2019. Constraints on the formation of granite-related indium deposits. Economic Geology, 114: 993-1003.

Jaskólski, S., 1948. Tin ore deposit in Gerbichy (Gieren) in Lower Silesia (preliminary report) (in Polish with English summary). Biuletyn Państwowego Instytutu Geologicznego, 42: 1-22.

Jaskólski, S., Mochnacka, K., 1959. Tin deposits at Gierczyn in Isera Mountains, Lower Silesia an attempt of elucidation their origin. Archiwum Mineralogiczne, 22: 17-106.

Jenner, F.E., O'Neill, H.S.C., 2012. Major and trace analysis of basaltic glasses by laser-ablation ICP-MS. Geochemistry, Geophysics, Geosystems, 13.

Johan, Z., 1988. Indium and germanium in the structure of sphalerite: an example of coupled substitution with copper. Mineralogy and Petrology, 39: 211-229.

Kozłowski, A., Ilnicki, S., Matyszczak, W., Marcinowska, A. 2016. Magmatic and post-magmatic phenomena in the Karkonosze granite and its metamorphic envelope (West Sudetes, SW Poland). Acta Geologica Polonica, 66: 456-476.

Kröner, A., Jaeckel, P., Hegner, E., Opletal, M., 2001. Single zircon ages and whole-rock Nd isotopic systematics of early Palaeozoic granitoid gneisses from the Czech and Polish Sudetes (Jizerské hory, Krkonoše Mountains and Orlice-Sněžník Complex). International Journal of Earth Sciences, 90: 304-324.

Kryza, R., Pin, C., Oberc-Dziedzic, T., Crowley, Q.G., Larionov, A., 2014. Deciphering the geochronology of a large granitoid pluton (Karkonosze Granite, SW Poland): an assessment of U-Pb zircon SIMS and $\mathrm{Rb}-\mathrm{Sr}$ whole-rock dates relative to $\mathrm{U}-\mathrm{Pb}$ zircon CA-ID-TIMS. International Geology Review, 56: 756-782.

Lerouge, C., Gloaguen, E., Wille, G., Bailly, L., 2017. Distribution of In and other rare metals in cassiterite and associated minerals in $\mathrm{Sn} \pm \mathrm{W}$ ore deposits of the western Variscan Belt. European Journal of Mineralogy, 29: 739-753.

Madziarz, M., Sztuk, H., 2006. Exploitation of the tin ore in the Izerskie Mountains: history or further perspective for the region? (in Polish with English summary). Prace Naukowe Instytutu Górnictwa Politechniki Wrocławskiej. Studia i Materiały, 117: 193-202.

Małek, R., Mikulski, S.Z., Chmielewski, A., 2019. The geochemical-mineralogical characteristic of cassiterite-sulphide mineral- 
ization in the historic Saint John and Saint Leopold shafts in the Stara Kamienica shist belt (Western Sudetes) (in Polish with English summary). Przegląd Geologiczny, 67: 914-924.

Mayer, W., Mochnacka, K., Janczyszyn, J., 1997. REE and trace elements in the schists of the Stara Kamienica Belt, Gierczyn area, SW Poland. Mineralogia Polonica, 28: 69-86.

Mazur, S., Aleksandrowski, P., 2001. The Tepla (?)/Saxothuringian suture in the Karkonosze-Izera Massif, western Sudetes, Central European Variscides. International Journal of Earth Sciences, 90: 341-360.

Michniewicz, M., Bobiński, W., Siemiątkowski, J., 2006. The mineralization in the middle part of the Stara Kamienica Schist Belt (Western Sudetes) (in Polish with English summary). Prace Państwowego Instytutu Geologicznego, 185: 5-136.

Mikulski, S.Z., 2007. Metal ore potential of the parent magma of granite - the Karkonosze massif example. Archivum Mineralogiae Monograph, 1: 123-145.

Mikulski, S.Z., Małek, R., 2019. Indium and other critical elements enrichment in cassiterite-sulphide mineralization from the stratiform tin deposits in the West Sudetes (SW Poland). Life with Ore Deposits on Earth. 15th SGA Biennial Meeting, 27-30 August 2019, Glasgow, Scotland, 4: 1818-1821

Mikulski, S.Z., Oszczepalski, S., Sadłowska, K., Chmielewski, A., Małek, R., 2018. The occurrence of associated and critical elements in the selected documented $\mathrm{Zn}-\mathrm{Pb}$, Cu-Ag, Fe-Ti-V, Mo-Cu-W, Sn, Au-As and Ni deposits in Poland (in Polish with English summary). Biuletyn Państwowego Instytutu Geologicznego, 472: 21-52.

Mochnacka, K., Mayer, W., Piestrzynski, A., Kucha, H., 1999. Petrology of cassiterite aggregates from Gierczyn area, SW Poland. In: Mineral Deposits: Processes to Processing (eds. Stanley et al.): 397-400. Balkema, Rotterdam.

Mochnacka, K., Pieczka, A., Gołębiowska, B., Kozłowski, A., 2001. Cassiterite from Rędziny and its relationship to the tinbearing schist of Izera area (SW Poland). In: Mineral Deposits at the Beginning of the 21st Century (eds. Piestrzyński et al.): 457-460. Balkema, Rotterdam.

Mochnacka, K., Oberc-Dziedzic, T., Mayer, W., Pieczka, A., 2015. Ore mineralization related to geological evolution of the Karkonosze-Izera Massif (the Sudetes, Poland) - towards a model. Ore Geology Reviews, 64: 215-238.

Oberc-Dziedzic, T., Pin, C., Kryza, R., 2005. Early Palaeozoic crustal melting in an extensional setting: petrological and Sm-Nd evidence from the Izera granite-gneisses, Polish Sudetes. International Journal of Earth Sciences, 94: 354-368.

Oberc-Dziedzic, T., Kryza, R., Mochnacka, K., Larinov, A., 2010. Ordovician passive continental margin magmatism in the Central-European Variscides: U-Pb zircon data from the SE part of the Karkonosze-Izera Massif, Sudetes, SW Poland. International Journal of Earth Sciences, 99: 27-46.

Onuk, P., Melcher, F., Mertz-Kraus, R., Gäbler, H.E., Goldmann, S., 2017. Development of a matrix-matched sphalerite reference material (MUL-ZnS-1) for calibration of in situ trace element measurements by laser ablation-inductively coupled plasma-mass spectrometry. Geostandards and Geoanalytical Research, 41: 263-272.

Pavlova, G.G., Palessky, S.V., Borisenko, A.S., Vladimirov, A.G. Seifert, T., Phan, L.A., 2015. Indium in cassiterite and ores of tin deposits. Ore Geology Reviews, 66: 99-113.

Piestrzyński, A., Mochnacka, K., 2003: Discussion on the sulphide mineralization related to the tin-bearing zones of the Kamienica schists belt (Western Sudety Mountains, SW Poland) (in Polish with English summary). In: Sudety Zachodnie - od wendu do czwartorzędu (eds. W. Cię kowski, J. Wojewoda and A elaźniewicz): 169-182. WIND, Wrocław.

Pinto, A., Relvas, J.M.R.S., Carvalho, J.R.S., Liu, Y., Pacheco, N., Pinto, F., Fonseca, R., 2014. High-tech metals in the zinc-rich massive ores of the Neves Corvo Deposit. Comunicaç es Geológicas, 101 (Especial II): 825-828.

Reiser, F.K., Rosa, D.R., Pinto, Á.M., Carvalho, J.R., Matos, J.X., Guimarăes, F.M., Alves, L.C., de Oliveira, D.P., 2011. Mineralogy and geochemistry of tin-and germanium-bearing copper ore, Barrigăo re-mobilized vein deposit, Iberian Pyrite Belt, Portugal. International Geology Review, 53: 1212-1238.

Schwarz-Schampera, U., 2013. Indium. In: Critical Metals Hand book (ed. G. Gunn):204-229. John Wiley and Sons.

Schwarz-Schampera, U., Herzig, P.M., 2002. Indium: Geology, Mineralogy, and Economics. Springer Science and Business Media, Berlin Heidelberg.

Seifert, T., 2015. Paragenesis, geochemistry and age of lateVariscan $\mathrm{Sn}$, In and $\mathrm{Ag}$ mineralization in the Marienberg district and its relationship to mafic and acidic magmatic events, Erzgebirge, Germany. In: Mineral Resources to Discover (eds. P. Mercier-Langevin et al.): 843-846. Balkema, Rotterdam.

Seifert, T., Sandmann, D., 2006. Mineralogy and geochemistry of indium-bearing polymetallic vein-type deposits: implications for host minerals from the Freiberg district, Eastern Erzgebirge, Germany. Ore Geology Reviews, 28: 1-31.

Słaby, E., Martin, H., 2005. Mechanisms of differentiation of the Karkonosze granite. Polish Mineralogical Society Special Papers, 26: 264-267.

Słaby, E., Martin, H., 2008. Mafic and felsic magma interaction in granites: the Hercynian Karkonosze Pluton (Sudetes, Bohemian Massif). Journal of Petrology, 49: 353-391.

Speczik, S., Wiszniewska, J., 1984. Some comments about stratiform tin deposits in the Stara Kamienica Chain (southwestern Poland). Mineralium Deposita, 19: 171-175.

Werner, T.T., Mudd, G.M., Jowitt, S.M., 2015. Indium: key issues in assessing mineral resources and long-term supply from recycling. Applied Earth Science, 124: 213-226.

Werner, T.T., Mudd, G.M., Jowitt, S.M., 2017. The world's by-product and critical metal resources part III: a global assessment of indium. Ore Geology Reviews, 86: 939-956.

Wilson, S.A., Ridley, W.I., Koenig, A.E., 2002. Development of sulfide calibration standards for the laser ablation inductively-coupled plasma mass spectrometry technique. Journal of Analytical Atomic Spectrometry, 17: 406-409.

Wittmann, A., 1974. Indium. A Crystal Chemistry. In: Handbook of Geochemistry (ed. K.H. Wedepohl). Springer-Verlag, Berlin.

Ye, L., Cook, N.J., Ciobanu, C.L., Yuping, L., Qian, Z., Tiegeng, L., Danyushevskiy, L., 2011. Trace and minor elements in sphalerite from base metal deposits in South China: a LAICPMS study. Ore Geology Reviews, 39: 188-217.

elaźniewicz, A., Nowak, I., Achramowicz, S., Czapliński, W. Cię kowski, A., Wojewoda, J., 2003. The northern part of the Izera-Karkonosze Block: a passive margin of the Saxothuringian terrane (in Polish with English summary). In: Sudety Zachodnie - od wendu do czwartorzędu (eds. W. Cie kowski, J. Wojewoda and A. elaźniewicz): 17-32. WIND, Wrocław.

elaźniewicz, A., Fanning, C.M., Achramowicz, S., 2009. Refining the granite, gneiss and schist interrelationships within the Lusatian-Izera Massif, West Sudetes, using SHRIMP U-Pb zircon analyses and new geologic data. Geologia Sudetica, 41: 67-84 